\title{
PSIKOTERAPI ISLAM PADA PASIEN GANGGUAN JIWA AKIBAT PENYALAHGUNAAN NARKOBA DI PONDOK INABAH BANJARMASIN
}

\author{
Fratiwi Rachmaningtyas* \& Mubarak** \\ *Alumni Jurusan Psikologi Islam Fakultas Ushuluddin dan Humaniora \\ IAIN Antasari Banjarmasin \\ **Dosen Jurusan Psikologi Islam Fakultas Ushuluddin dan Humaniora \\ IAIN Antasari Banjarmasin
}

\begin{abstract}
South Kalimantanprovince is currently rated sixth in the case of drug abuse. On the other hand, the province of South Kalimantan is a province with Islamic society culture. It should be able to become a filter to form a bealthy society, since Islam has a complete concept of physically and psychologically health. From the reality, the writer looked that Islamic psychotherapy could be an option as psychotherapy for patients with mental disorder caused by drug abuse and contemporary psychotherapy in addition to obtain the optimal health. Because the Islamic psychotherapy concept is proven to help deal with the psychological problems. Then, Pondok Inabab' is one of the places which uses Islamic psychotherapy chosen as the study site. This study aims to describe patients who suffer from mental disorders due to drug abuse and to find the Islamic psychotherapy techniques applied to patients with mental disorders as a result of drug abuse in Pondok Inabab'. The research finding can be used as the scientific literature for scholars working in the field of psychology; general and Islam. The materials study can be used by the practitioners who work in the field of psychotherapy, both psychologists and muslim therapists and as well as information material for the general public who is interested or has intention on the topic of Islamic psychotherapy for patients with mental disorders due to drugs.
\end{abstract}

Kata kunci: psikoterapi Islam, gangguan mental, obat, pondok inabah.

\section{Pendahuluan}

Manusia merupakan makhluk ciptaan Allah yang memiliki struktur fisik dan psikis yang sempurna. Manusia dikaruniai Allah kecenderungan yang inheren dalam dirinya untuk selalu mengarah pada nilai-nilai kebaikan (agama). Kecenderungan ini dalam Islam disebut fitrah. ${ }^{1}$

Dalam kehidupan sehari-hari, manusia sebagai makhluk yang memiliki berbagai motivasi dalam menjalani kehidupannya ${ }^{2}$ seringkali dihadapkan pada beberapa pilihan-pilihan untuk memenuhi motif(kebutuhan) dalam hidupnya. Jika manusia tidak dapat mengendalikan motifnya dengan baik serta memenuhi kebutuhan motif secara wajar, maka secara naluriah manusia akan mengalami penyimpangan dari fitrahnya. ${ }^{3}$ Keadaan menyimpang dari fitrah iniakan memunculkan perilaku yang menyimpang, karena hati tidak condong kepada kebaikan ${ }^{4}$.

\footnotetext{
${ }^{1}$ Moh. Sholeh, Agama sebagai Terapi, (Yogyakarta: Pustaka Pelajar, 2005.), h. 36.

${ }^{2}$ Ustman Najati, Ultimate Psychology, (Bandung: Pustaka Hidayah, 2008.), h. 74.

${ }^{3}$ Ustman Najati, Ultimate Psychology, h. 75.

${ }^{4}$ M. Izzudin Taufiq, Panduan Lengkap dan Praktis Psikologi Islam, (Jakarta: Gema Insani Press, 2006.), h. 477.
} 
Manusia yang tidak mampu menyeimbangkan kepribadian dirinya dalam memenuhi segala kebutuhan tubuh dan kebutuhan spiritualnya dengan baik sesuai apa yang disyariatkan Islam, dikatakan tidak mampu pula mewujudkan kesehatan diri dan jiwanya. ${ }^{5}$

Diantara gangguan kejiwaan terdapat gangguan kejiwaan akibat ketergantungan narkoba yang bersumber dari pemenuhan motif fisik yang tidak sesuai dengan tuntunan Islam yang mengharamkan meminum (mengkonsumsi) segala sesuatu yang bersifat memabukkan. ${ }^{6}$

Masyarakat Kalimantan Selatan dekat dengan nilai-nilai religius, utamanya Islam, dengan jumlah penduduk yang mayoritas beragama Islam. ${ }^{7}$ Pengaruh agama Islam di Kota Banjarmasin sangat kuat terhadap segala aspek kehidupan sosial dan budaya masyarakat. Oleh karena itu, sikap dan persepsi masyarakat terhadap berbagai masalah sangat ditentukan oleh pendekatanpendekatan Islami yang menjadi pedoman kehidupan pemeluknya. ${ }^{8}$

Demikian halnya dengan upaya penyembuhan gangguan kejiwaan akibat penyalahgunaan narkoba, beberapa alternatif terapi religius yang dipadukan dengan terapi medis menjadi salah satu pilihan terapi yang dilirik oleh pemerintah. Penatalaksanaan terapi penyalahgunaan narkoba dalam peraturan undang-undang, terdiri dari berbagai macam model terapi, salah satu yang menarik adalah terapi yang bersifat terapi alternatif, termasuk terapi pengguna narkoba lewat pondok pesantren. ${ }^{9}$

Dalam Psikoterapi Islam, penyembuhan-penyembuhan yang paling utama dan sangat mendasar adalah pada eksistensi dan esensi jiwa dan spiritual manusia, yang akan menjadikan manusia terampil, cerdas, dan bijaksana. ${ }^{10}$ Di dunia Barat pun telah ditemukan bukti-bukti yang menunjukkan korelasi antara kondisi religius seseorang dangan tingkat kesembuhan. ${ }^{11}$

Psikoterapi islam diperlukan berdasarkan sudut pandang muslim, yang menjadikan Alqur'an dan As Sunah sebagai sumber ilmu. Dimana pada kedua sumber tersebut, Allah, sebagai pencipta manusia telah memberikan solusi terbaik bagi masalah kejiwaan manusia. ${ }^{12}$ Sebagaimana firman-Nya dalam al-Qur'an Surah Yunus/10: 57 yang menyatakan Allah telah menurunkan alQur'an sebagai pelajaran dan penyembuh bagi penyakit-penyakit yang berada didalam dada

Namun psikoterapi Islam sendiri tidak menutup diri terhadap konsep psikoterapi Barat yang bersesuaian dengan nilai Islam sebagai upaya untuk mengembalikan kesehatan mental seseorang kepada fitrahnya. "13 "kehadiran psikologi Islam sebagai mainstream baru dalam perkembangan psikologi dianggap sebagai Psikologi Alternatif yang menelusuri alam dunia dan akhirat. Untuk itulah Psikologi Islam diharapkan dapat membantu mengatasi berbagai permasalahan manusia dewasa ini." 14

\footnotetext{
${ }^{5}$ Musfir bin Said Az Zahrani, Konseling Terapi (Jakarta: Gema Insani Press, 2006.) h. 451.

${ }^{6}$ Ustman Najati, Ultimate Psychology, h. 51-52.

${ }^{7}$ Kemenag Kal Sel, Data Pemeluk. Agama, (kalsel.kemenag.go.id, 15/08/2013. 2011).

${ }^{8}$ Wajidi, Asal Usul Etnis Banjar, (http://bubuhanbanjar.wordpress.com, 15/08/2013. , 2010).

${ }^{9}$ Keputusan Menteri Kesehatan RI, No. 420/menkes/SK/III/2010 tentang Pedoman Layanan Terapi dan Rehabilitasi Komprehensif pada Gangguan Penggunaan Napza(narkotika Psikotropika dan Zat Adiktif lainnya) berbasis Rumah Sakit.

${ }^{10}$ Hamdani Bakran Adz Dzaky, Konseling dan psikoterapi Islam..., h. 253.

${ }^{11}$ Moh Sholeh, Agama sebagai terapi, h. 141-142.

${ }^{12}$ Moh Sholeh, Agama sebagai terapi, h. 252.

${ }^{13}$ Moh Sholeh, Agama sebagai terapi, h. 251.

${ }^{14}$ Siti Faridah, Psikologi Islam: Psikologi Alternatif dalam Memahami dan Memecabkan Masalah Kejiwaan, disampaikan dalam workshop perkembangan Psikologi Islam, (Banjarmasin: Fakultas Ushuluddin IAIN ANTASARI, 2008).
} 
Masalah yang akan dibahas dalam penelitian ini dirumuskan menjadi a). Bagaimana gambaran pasien yang menderita gangguan jiwa akibat penyalahgunaan narkoba? Teknik Psikoterapi Islam apa saja yang diterapkan pada pasien gangguan jiwa akibat penyalahgunaan narkoba di Pondok Inabah?

\section{Tinjauan Umum Psikoterapi Islam}

\section{Kesehatan Jiwa dalam Psikologi Islam}

Jiwa yang sehat dapat mencerminkan fisik yang sehat, demikian pula sebaliknya, sehingga kesehatan jiwa memandang keadaan manusia sebagai satu kesatuan psikofisik yang kompleks yang lebih mengarah kepada kehidupan kerohanian seseorang. "' "Kesehatan jiwa...adalah bersih jiwa dari..energi yang menggerakkan jiwa untuk melahirkan sikap...yang menyimpang dari apaapa yang telah digariskan oleh wahyu ketuhanan (al-Qur'an) dan sabda kenabian (as-Sunah).”16

Islam memandang manusia sebagai satu kesatuan yang utuh, yakni fisik dan psikis, ruh dan jasad, sehingga sehat dalam dimensi Islam mencakup sehat jasmani dan rohani.Keadaan abnormal pada batin manusia berpengaruh pada terjadinya abnormalitas pada keadaan fisiknya ${ }^{17}$. Keadaan batin manusia yang sehat adalah jiwa yang terbebas dari berbagai jenis penyakit hati (amaratul qulub) $)^{18}$

Keadaan jiwa manusia yang sesuai dengan fitrah Islam, yakni kebaikan dan keimanan adalah pengantar untuk mewujudkan kesehatan jiwa. Manusia yang berada pada kondisi ini akan berhasil membedakan perbuatan baik dan buruk, sedangkan yang menjadi ragu-ragu ataupun tidak berhasil membedakan kebatilan dan kebenaran menunjukkan adanya ketidakstabilan dalam kesehatan jiwanya. ${ }^{19}$

Beberapa ilmuan muslim mendefinisikan standar khusus dalam menentukan indikator kesehatan jiwa:

a. Ustman Najati

1) Memiliki kesesuaian hubungan individu dengan Tuhannya dengan mentaati perintahNya dan menjauhi laranganNya.

2) Mampu mengetahui potensi dirinya, serta dapat mengendalikan motif yang tidak selaras dengan ajaran Islam.

3) Mampu berjuang untuk mengatasi persoalan hidupnya.

4) Dapat menjalin hubungan yang baik dan bertanggung jawab dengan orang lain.

\footnotetext{
${ }^{15}$ Moh.Sholeh, Agama Sebagai Terapi (Yogyakarta: Pustaka Pelajar, 2005.), h. 21-22.

${ }^{16}$ Hamdani Bakran AZ-Zakiey, Psikologi Kenabian (Yogyakarta: al-Manar, 2008.), h. 113.

${ }^{17}$ M. Izzudin Taufiq, Panduan Lengkap dan Praktis Psikologi Islam, h. 469. Islam dalam sisi spritualitasnya memiliki konsep selaras dengan kesehatan mental kontemporer, dimana keduanya memandang bahwa setiap perbuatan buruk yang tercermin lewat perilaku adalah indikasi dari rendahnya kondisi kesehatan mental seseorang. Demikian sebaliknya, bahwa perbuatan baik atau akhlak terpuji menjadi penghantar bagi terwujudnya kesehatan mental yang baik, lihat Yahya Jaya, Spiritualisasi Islam Dalam Menumbubkembangkan Kepribadian dan kesehatan Mental, (Jakarta: 1994.), h. 80-81.

${ }^{18}$ Abdul Mujib, Nuansa-nuansa psikologi Islam, (Jakarta: Raja Grafindo Persada, 2002.), h. 386.

${ }^{19}$ Izzudin Taufiq, Panduan Lengkap, h. 479. Fitrah jiwa cenderung pada kesucian, suara hati manusia mencegah perbuatan buruk, manusia yang tidak melakukan latihan terhadap pengendalian nafsunya akan cenderung jatuh pada keburukan, demikian pula sebaliknya.
} 
5) Mampu mengaplikasikan hukum-hukum Allah di muka bumi agar menciptakan kemakmuran masyarakat. ${ }^{20}$

b. M. Audah Muhammad

1) Dimensi Spiritual, dengan beriman kepada Allah, melaksanakan ibadah, mengetahui dan mematuhi apa yang halal dan apa yang haram baginya.

2) Dimensi Psikis, dimana seseorang dapat menerima dirinya apa adanya, dapat membangun konsep diri yang baik sehingga tidak memiliki rasa iri, dengki ataupun sombong.

3) Dimensi Sosial, dimana seseorang dapat mencintai orang tua, saudara-saudaranya, istri, anak, serta saudara seakidah dengan wajar. Dapat mengetahui dan menjauhi halhal yang dapat menyakiti sesama manusia sehingga ia dapat bergaul dengan masyarakat dengan baik.

4) Dimensi Biologis, dimana seseorang memliki tubuh yang sehat dan jauh dari penyakit, serta mempunyai rasa tanggung jawab atas keadaan fisiknya dengan tidak membebani fisiknya dengan aktivitas diluar kemampuan. ${ }^{21}$

\section{Pengertian Psikoterapi Islam}

Dalam kamus psikologi, psikoterapi adalah penerapan teknik khusus pada penyembuhan penyakit mental atau pada kesulitan penyesuaian-penyesuaian diri setiap hari.Lebih longgar lagi, psikoterapi dapat mencakup pula suatu pembicaraan informal dengan para menteri atau duta, penyembuhan lewat keyakinan agama, dan diskusi personal dengan para guru atau teman. ${ }^{22}$

Psikoterapi Islam, adalah proses pengobatan dan penyembuhan suatu penyakit, baik mental, spiritual, moral, maupun fisik, dengan mengacu pada apa yang ditunjukkan dalam al-Qur'an dan hal-hal yang diterangkan Nabi Muhammad SAW melalui sunah beliau. ${ }^{23}$ Islam telah megajarkan penyembuhan jiwa sejak zaman Rasulullah melalui al-Qur'an sebagaimana firman Allah dalam Surah al-Isra/17: 82 yang menyatakan bahwa al-Qur'an telah diturunkan sebagai penawar bagi orang-orang yang beriman.

Terapi dalam Islam, layaknya pandangan Islam dalam kesehatan mental, juga memiliki dua aspek, yakni fisik dan psikis. Gangguan yang terjadi pada fisik manusia secara sunatullah diterapi dengan hal yang bersifat fisik, yakni obat-obatan yang sesuai dengan hukum syara, sementara gejala gangguan yang muncul dalam jiwa diterapi dengan pengobatan ma'nawi, yakni terapi yang menjadi nutrisi bagi ruh dan kalbu manusia yang sedang sakit. ${ }^{24}$

Dalam terapi Islam terdapat nilai sosial yang dilakukan, seorang terapis juga menjadi teladan bagi kliennya sebagai agen perubahan bagi dirinya. Sebagai cerminan bahwa perubahan yang diinginkan dapat terjadi pada siapa saja asalkan disertai dengan niat yang ikhlas dan keinginan yang kuat untuk keluar dari kegelisahan.

\footnotetext{
${ }^{20}$ Izzudin Taufiq, Panduan Lengkeap, h. 447.

${ }^{21}$ Izzudin Taufiq, Panduan Lengkap, h. 449.

22 JP Chaplin, Kamus Lengkeap Psikologi, h. 408.

${ }^{23}$ Hamdani Bakran AZ Zaky, Psikologi Kenabian, (2007.), h. 228.

${ }^{24}$ Abdul Mujib, Nuansa-Nuansa, h. 209.
} 
Dalam Islam, psikoterapi Islam dekat dengan upaya pembersihan jiwa, karena penyucian jiwa -istilah lain untuk pembersihan jiwa dalam Islam- adalah jalan untuk mencapai kondisi fitrah pada manusia ${ }^{25}$ yang mengantarkannya pada kesehatan mental.

\section{Metode Psikoterapi Islam}

Metode yang dapat digunakan secara luas untuk mencapai kesehatan mental adalah metode: 1) Imaniab, yang secara harfiah berarti rasa aman, yakni orang yang beriman jiwanya merasa tenang dan sikapnya penuh keyakinan dalam menghadapi semua problema hidup. Yang membentuk karakter rabbani, qur'ani, malaki, rasuli, berwawasan hari akhir, dan taqdiri; 2) Islamiah, secara etimologi bermakna penyerahan, ketundukan, dan keselamatan. Seseorang yang tunduk patuh terhadap aturan Allah niscaya kehidupannya akan damai. Yang membentuk karakter syahadatain, mushalli, muqakki, sha'im, hajji; 3). Ibsaniah, secara bahasa berarti baik, mengetahui hal-hal yang baik, melakukan prosedur yang baik, dan dilakukan dengan niat yang baik, yang membentuk kepribadian mubsin.

Dalam metodologi tasanmuf, metode psikoterapi Islam berupa proses: 1) Takballi, yaitu pengosongan diri dari dosa-dosa yang pernah dilakukannya dengan melakukan tobat untuk mensucikan dirinya; 2) Taballi, yakni mengisi diri yang telah kosong tadi dengan ibadah dan ketaatan; 3) Tajalli, yakni hadir, tampaknya Allah pada hamba yang dikehendakiNya. ${ }^{26}$

Metode-metode psikoterapi Islam diatas dapat dijalankan dengan melaksanakan ibadah yang terdapat dalam Islam, diantaranya :

\section{Psikoterapi dengan Shalat}

Shalat bagi seorang mukmin adalah kewajiban yang dilakukan lima kali dalam sehari, yang menjadi pelebur dosa yang dilakukannya dalam hari itu, shalat dengan ikhlas akan membersihkan pelakunya serta mencegahnya dari perbuatan keji. ${ }^{27}$ Shalat yang membekas di dalam jiwa seseorang adalah shalat yang khusyu, yang didapat melalui ilmu dan latihan yang benar. Hal ini sebagaimana dicontohkan Rasulullah yang menjadikan shalat sebagai penawar rasa gundah ketika menghadapi suatu masalah, serta menjadikan shalat sebagai sarana untuk relaksasi. Sebagaimana firman Allah dalam al-Qur'an Surah al-Baqarah/ 2 : 45 yang mengajarkan hambaNya untuk menjadikan sabar dan shalat sebagai sarana meminta tolong kepadaNya.

Shalat dapat mendekatkan ruh manusia pada tuhanNya yang menjadikan hati menjadi tenang, tegar dan lapang, bahagia serta tentram. Hati yang demikian terhindar dari penyakit hati yang akan merusak jiwa seseorang, ia akan menjadi pribadi yang dapat meredam hawa nafsu, dirahmati Allah, senang membantu dan tidak diliputi kegundahan. ${ }^{28}$

${ }^{25}$ Jaelani, Penyucian Jiwa (Tazkiyat al Nafs) dan Kesehatan Mental, (2001.), h. 112.

${ }^{26}$ Hamdani, Konseling, h. 259-270. Metode ini menjadi hal yang umum digunakan dimasyarakat sekarang ini, dimana sebelum menghendaki kondisi kejiwaan-dan spiritual- yang lebih baik, seseorang seharusnya lebih dulu mensucikan dirinya dari dosa masa lalu.

${ }^{27}$ Moh Sholeh, Agama sebagai terapi, h. 143-145.

${ }^{28}$ Ibnu Qayyim Al-Jauziyyah, Ath-Thibb an-Nabawi, dalam Ultimate Psychology, h. 380-381. 


\section{Psikoterapi dengan Zikir dan Membaca al- Qur'an}

Zikir secara literal berarti mengingat, sementara dalam pengertian lain zikir dapat bermakna bentuk kesadaran yang dimiliki seseorang makhluk akan hubungan yang menyatukan seluruh kehidupannya dengan sang Pencipta. ${ }^{29}$

Zikir merupakan salah satu cara hamba berkomunikasi dengan Tuhannya, dengan membersihkan diri dari kesenangan dunia dan mensucikan ruh dengan mendekatkannya pada Allah. ${ }^{30}$ Zikir terdapat dalam beberapa bentuk, ada yang dengan suara yang jelas (jahr) adapula dengan melafazkan di dalam hati (khofi), ada yang dilakukan sendiri adapula yang dilakukan dengan mengikuti kelompok dengan teknik-teknik tertentu. ${ }^{31}$ Zikir yang dilakukan secara kolektif dapat menguatkan niat dan taqwa seseorang, serta menumbuhkan perasaan persaudaraan dan tolong menolong yang kuat dalam satu kehidupan sosial, sehingga akan melahirkan individu yang tidak mudah berputus asa serta tidak takut terhadap permasalahan kehidupan. ${ }^{32}$

\section{Psikoterapi dengan Doa}

Doa sebagai penyembuh dari rasa cemas dan menjadi katarsis bagi orang tersebut dan ucapan-ucapan baik yang dilafazkannya menjadi auto sugesti bagi dirinya. ${ }^{33}$ Doa dapat menjadi bentuk permintaan untuk diri sendiri (petisi), permohonan untuk orang lain (intercesi), pengakuan dan penyesalan atas kesalahan serta meminta pengampunan (konfesi), berseru dalam kondisi sesak dan memohon ampun (lamentasi), memberikan penghormatan dan tujuan (adorasi), menginginkan kehadiran Tuhan (Invokasi), serta menyampaikan rasa syukur kepada Nya. ${ }^{34}$

\section{Psikoterapi dengan Puasa}

Dalam Ihya' Ulumiddin, dikatakan bahwa lapar memiliki beberapa faedah, diantaranya: 1) Bersihnya hati; 2) Dapat merasakan lezatnya berzikir; 3) Hilangnya kesombongan dan kufur nikmat; 4) Mengingat siksa Allah dan mengingat orang-orang yang sedang tertimpa bencana; 5) Memudahkan ibadah malam. ${ }^{35}$

Puasa adalah sarana bagi seseorang untuk belajar patuh dan takut pada Allah, senantiasa merasa diawasi, sehingga tidak mudah melakukan perbuatan buruk, kendati tidak ada seorangpun yang menyaksikan. Melatih kesabaran seseorang agar dapat memperoleh apa yang diinginkannya di waktu-waktu yang telah ditentukan. Keadaan yang melatih jiwa ini diharapkan dapat menundukkan jiwa manusia, sehingga menjadi suci dan sabar.

\section{Psikoterapi dengan Tobat}

Tobat bermakna kembali ke asal, membuat jiwa seseorang kembali lagi sesuai dengan kodrat asalnya yang fitri. ${ }^{36}$ Seseorang akan meninggalkan hal yang haram dan mengutamakan

${ }^{29}$ Rizki Joko Sukmono, Psikologi Zikir, (Jakarta: Raja Grafindo, 2008.), h. 33.

${ }^{30}$ Amir An Najar, Ilmu Jiwa dalam Tasawmuf(Bandung: Mizan, 2004.), h. 218-219.

${ }^{31}$ M.A Subandi, Psikologi Zikir, (Yogyakarta: Pustaka Pelajar, 2009.), h. 34-35.

${ }^{32}$ Amir An Najar, Ilmu Jiwa dalam Tasawnuf, h. 220.

${ }^{33}$ Ustman Najati, The Ultimate Psychology, h. 398-399.

${ }^{34}$ Menurut Larry Dossey, dalam buku Mustamir, Potensi SQ, EQ, IQ AlFaatihah, (Jakarta: Diva Press, 2009.), h. 287.

${ }^{35}$ Al-Ghazali, Ihya' Ulumiddin, terjemah Ihya' Ulumiddin jilid 5, terj.Moh. Zuhri, et al., (Semarang: Asy-Syfa, 2009.), h.219-231.

${ }^{36}$ Hasyim Muhammad, Dialog antara Tasawuf dan Psikologi, (Bandung: Pustaka Pelajar, 2002.) h. 30. 
melakukan kebaikan-kebaikan penuh tekad menuju kepada Allah. ${ }^{37}$ Tobat memiliki dua hal penting yakni ilmu dan sabar, ia mengetahui dengan ilmu melalui ulama bahwa kesalahan yang dilakukannya adalah sumber dosa-dosa. Kemudian melakukan upaya pembersihan jiwa sesuai arahan ulama dengan sabar. ${ }^{38}$

Tobat membuka harapan bagi manusia akan kehidupan yang baru, tanpa bayangan masa lalu, serta menjadi aktifitas yang senantiasa diperbaharui agar semakin mengokohkan lembar yang masih putih. Serta berusaha untuk terus melatih jiwanya agar tidak tergiur kembali untuk berbuat maksiat. ${ }^{39}$

\section{Penyalahgunaan Narkoba dan Dampak Psikologisnya}

Narkoba adalah singkatan dari narkotika dan obat-obatan terlarang, dalam istilah medis lebih dikenal dengan istilah NAPZA (narkotika, alkohol, psikotropika dan zat adiktif lain). ${ }^{40}$

Penggolongan NAPZA dapat dibagi berdasarkan dua hal, yakni:

Berdasarkan Undang-Undang, narkotika digolongkan menjadi tiga golongan : 1) Golongan I, yaitu narkotika yang tidak digunakan untuk terapi; 2) Golongan II, yaitu narkotika yang dapat digunakan untuk terapi; 3) Golongan III, yaitu narkotika yang digunakan untuk terapi dan berpotensi rendah untuk ketergantungan,

Berdasarkan efek terhadap susunan syaraf pusat: 1) Depresan, yakni zat yang bekerja menekan susunan syaraf pusat; ${ }^{41}$ 2) Stimulant, yakni zat yang mempunyai khasiat merangsang kerja otak; ${ }^{42}$ 3) Halusinogen, yakni zat yang dapat menimbulkan efek halusinasi ${ }^{43}$

Penyalahgunaan NAPZA adalah penggunaan NAPZA yang bersifat patologis, paling sedikit telah berlangsung satu bulan lamanya sehingga menimbulkan gangguan dalam pekerjaan dan fungsi sosial. ${ }^{44}$

Ketergantungan terhadap NAPZA dibagi menjadi dua, yaitu: 1) Ketergantungan Fisik, adalah keadaan bila seseorang mengurangi atau menghentikan penggunaan NAPZA yang biasa ia gunakan, ia akan mengalami gejala putus zat dan dapat ditandai dengan adanya toleransi ${ }^{45}{ }^{4}$ ) Ketergantungan Psikologis, adalah keadaan bila seseorang berhenti menggunakan NAPZA tertentu, ia akan mengalami gejala kerinduan yang sangat kuat untuk menggunakan NAPZA tersebut kembali, walaupun ia tidak mengalami gejala fisik. ${ }^{46}$ Ketergantungan psikis dikatakan juga kebutuhan mental akan efek psikotrop, yakni rasa nyaman dan segar, yang dapat menjadi sangat kuat, sehingga pasien seolah-olah terpaksa melanjutkan penggunaan obat. ${ }^{47}$

\footnotetext{
${ }^{37}$ Amir An Najar, Psikoterapi Sufistik dalam Kebidupan Modern, Mizan, (Bandung: 2004.), h. 45.

${ }^{38} \mathrm{Al}-$ Ghazali, Ihya' Ulumiddin, terjemah Ihya' Ulumiddin jilid 7, terj. Moh. Zuhri, et al., (Semarang: Asy-Syfa, 2009.), h. 280-281.

${ }^{39}$ An Najar..., Ilmu Jiwa dalam tasawnuf h.235-236.

${ }^{40}$ Sumiati M,si, AsubanKeperawatan pada Klien Penyalahgunaan dan Ketergantungan NAPZA, (2009.), h. 7.

${ }^{41}$ Siegfried Ebel, Synthetische Arzneimittel Ein lehr Und Handbugh, terj. Obat Sintetik sebuah buku pegangan, (1992.), h. 187-221.

${ }^{42}$ Dr. Amir Syarif, et al, Farmakologi dan terapi,(1995.), h.223-233.

${ }^{43}$ Julianan Lisa FR dan Nengah Sutrisna, Narkoba, Psikotropika dan Gangguan Jiwa, (Jakarta: Nuha Medika 2013.), h. 27.

${ }^{44}$ Sumiati M,si, Asuban Keperawatan ..., (2009.), h. 8.

${ }^{45}$ Tan Hoan Tjay dan Kirana rahardja, Obat-Obat Penting, (Jakarta: Penerbit Gramedia 2002.), h. 336.

${ }^{46}$ Julianan Lisa FR., Narkoba, Psikotropika dan Gangguan Jiwa, Nuha Medika, 2013, h. 35.

${ }^{47}$ Tan Hoan Tjay dan Kirana rahardja, Obat-Obat Penting, (Jakarta: Penerbit Gramedia, 2002.), h. 328-329.
} 
Pada tahap penyalahgunaan, dampak psikologis yang muncul pada diri pengguna adalah: 1) Menggunakan secara teratur, dalam beberapa kali seminggu, lebih sering menggunakan sendirian daripada dengan teman-teman; 2) Membeli dan menyimpan untuk persediaan untuk digunakan sendiri serta mencuri untuk mendapatkan uang untuk membeli zat; 3) Untuk memanipulasi emosi, pengguna mendapatkan kesenangan efek penggunaan zat, sebagai koping terhadap stress dan perasaan-perasaan tidak nyaman, seperti sakit hati, perasaan bersalah, cemas, sedih, serta untuk meningkatkan kepercayaan diri; 4) Untuk menghilangkan perasaan gelisah ketika tidak menggunakan, serta untuk mendapatkan perasaan normal, yang muncul dalam bentuk euphoria; 5) Pengguna mulai mengurangi aktifitas sosial dengan orang lain, mengadopsi gaya hidup dari pengguna lain, seperti pakaian, cara berbicara dan gaya rambut; 6) Mulai memiliki sikap membangkang, dan bermasalah dengan keluarga, karena perhatian hidupnya hanya pada cara memperoleh uang untuk membeli narkoba. ${ }^{48}$

\section{Teknik Psikoterapi Islam Pada Pasien Gangguan Kejiwaan}

Berdasarkan pengamatan terhadap pasien lain dan hasil wawancara dengan terapis dan perawat pengelola di Pondok Inabah, gambaran teknik Psikoterapi Islam yang dilakukan di Pondok Inabah Banjarmasin adalah:

\section{Mandi tobat}

Adalah mandi yang dimaksudkan untuk mensucikan pasien dari hadas besar yang mungkin ia kerjakan pada keadaan tidak sadar, ataupun dikarenakan ia tidak mengetahui kewajiban mandi janabah tersebut. Serta diharapkan dapat menghantarkan pada awal kondisi suci pasien.

Proses ini biasanya dilakukan pada hari pertama pasien tiba di Pondok Inabah Banjarmasin. Namun, jika pasien tersebut mengamuk atau terlalu murung pada saat pertama kali datang, maka proses ini dilakukan pada hari kedua atau ketiga. Jika tidak, maka dilakukan pada saat pasien siap dan mampu beradaptasi.

Rukun mandi tobat juga seperti mandi janabat, yakni: 1) Membaca niat di dalam hati, dengan lafaz "sengaja aku mandi wajib untuk menghilangkan hadas besar karena Allah Ta'ala". Terapis tetap menbacakan niat, baik pasien mampu membaca niat ataupun tidak bisa membaca niat; 2) Menghilangkan kotoran dan najis yang melekat di badan, sehingga pasien berada pada keadaan yang bersih; 3) Meratakan air keseluruh anggota badan yang zahir termasuk segala lipatan-lipatan badan.

\section{Shalat dengan khusyuk}

Pasien diajarkan dan dipaksa bagi pasien yang tidak mau, untuk mengerjakan shalat wajib dan sunnah pada waktu tertentu. Shalat dikerjakan dengan hati yang dihadirkan untuk Allah dan gerakan yang benar dan disertai tuma'ninah.

Shalat yang dilakukan adalah: 1) Dua rakaat shalat sunah sebelum subuh; 2) Dua rakaat shalat subuh; 3) Dua rakaat shalat sunah isyrak; 4) Dua rakaat shalat sunah istikharah di waktu Dhuha; 5) Delapan rakaat shalat sunah Dhuha; 6) Dua rakaat shalat sunnah sebelum dan sesudah

\footnotetext{
${ }^{48}$ Sumiati M. Si, Asuban Keperawatan, 2009, h. 30-31
} 
Dzuhur; 7) Empat rakaat shalat Dzuhur; 8) Dua rakaat shalat sunah sebelum Ashar; 9) Empat rakaat shalat Ashar; 10) Dua rakaat shalat sunah sebelum dan sesudah shalat maghrib; 11) Tiga rakaat shalat Maghrib; 12) Dua rakaat shalat sunah tobat; 13) Dua rakaat shalat sunah sebelum dan sesudah shalat Isya; 14) Empat rakaat shalat Isya; 15) Dua rakaat shalat Hajat; 16) Dua rakaat shalat istikharah sesudah shalat Hajat; 17) Enam rakaat shalat tahajjud; 18) Empat rakaat shalat tasbih setelah tahajjud; 19) Tiga rakaat shalat witir.

\section{Zikir}

Saat melakukan zikir jahar, pasien dan terapis memulainya dengan ucapan "La" dari pusat dan diangkat sampai ke otak (Lathifah Nafsi Nathiqah) dalam kepala, sesudah itu diucapkan "Tlaha" dari arah kepala dengan menurunkan perlahan-lahan ke bahu kanan.

Lalu memulai lagi mengucapkan "Illa Allah" dari bahu kanan menurunkan kepala pada dada sebelah kiri dan diakhiri menuju hati yang terletak dibawah tulang rusuk, dengan menghembuskan lafazh "Allab" sekuat mungkin. Zikir ini diucapkan sebanyak seratus enam puluh lima kali disetiap selesai shalat fardhu yang dilakukan, juga pada beberapa shalat sunah seperti dhuba dan tahajjud.

Pasien diharapkan dapat merasakan gerak dan kekuatan zikir tersebut di seluruh bagian tubuh yang diarahkan tadi untuk menghancurkan seluruh dosa-dosa yang terdapat pada bagian tubuh tersebut dengan merasakan cahaya Nur Ilahi. Setelah menyelesaikan lafaz dan gerakan zikir terapis dan pasien mengakhirinya dengan membaca "Sayyiduna Muhammad al-Rasul Allah Sala Allah alaibi wa al-salam”.

Pada awalnya zikir ini dilantunkan dengan suara yang datar, namun lama kelamaan menjadi nyaring dan berirama kuat, kemudian menjadi turun intonasinya mendekati bagian akhir zikir.Pada beberapa keadaan, terapis dan pasien menggerak-gerakkan badan dan kepalanya mengikuti irama zikir dengan kuat.

Saat melakukan zikir khafi (zikir Qalb), mata pasien dipejamkan, lidah ditegakkan ke langitlangit mulut, bibir dan gigi dirapatkan dan ditahan nafas dengan kuat. Yang dikatakan bertujuan untuk menahan angin dan syaitan tidak masuk ke dalam mulut pasien.Kemudian kepala ditundukkan ke bawah dada kiri dengan melemaskan badan, sementara dalam hati membaca kalimat "Allah, Allah" dengan tetap menahan nafas dengan kuat. Setelah zikir ini berakhir, terapis dan pasien juga melantunkan shalawat, kemudian membaca doa, setelah itu pasien dan terapis berdiri berputar untuk bersalam-salaman. ${ }^{49}$

\section{Berdoa}

Setelah shalat berjamaah dan setelah pak ustaz selesai memimpin zikir dan membaca wirid shalat, pada waktu tertentu seperti setelah shalat Isya atau setelah shalat Tahajjud, pasien diminta untuk merenungkan kesalahannya di masa lalu. Dengan menghadirkan prasangka baik kepada Allah, bahwa Ia adalah Zat yang Maha Pengampun, yang mendengar setiap pinta dan harap setiap manusia.

\footnotetext{
${ }^{49}$ Mursyidi, terapis Pondok Inabah, sebagai Informan, wawancara dan Observasi di Pondok Inabah, Banjarmasin, Desember 2013.
} 
Memohon ampun bagi kedua orang tua dan berjanji akan selalu membahagiakan orang tua dengan menjadi hamba yang taat. Kemudian memohon kesabaran dan kebaikan bagi diri sendiri, bagi guru, serta bagi keluarga agar kesembuhan yang dinanti segera tiba.

Pasien yang menghayati dan tersentuh hatinya dengan kondisi ini dikatakan tampak menitikkan air mata dan menyatakan penyesalannya akan perbuatan buruknya yang telah lalu. Mereka menyesal telah menyia-nyiakan waktu yang diamanahkan Allah dalam hidupnya, serta menyesal tidak menuruti kebaikan-kebaikan yang diajarkan oleh orang tuanya.

Terapis memotivasi pasien bahwa Allah adalah Tuhan yang Maha Pengampun, yang mengampuni dosa yang kecil juga dosa besar. Asalkan dengan keinginan yang kuat untuk bertobat, dan tidak lagi mengulang apa yang terjadi di belakang, insya Allah ampunan-Nya datang untuk membersihkan jiwa yang kotor.

\section{Puasa}

Semua pasien diajak untuk menjalankan puasa sunah Senin dan Kamis, hal ini dimaksudkan untuk melatih jiwa pasien dalam mengekang keinginannya menuruti hawa nafsu. Terapis mengajak pasien untuk menamamkan niat yang kuat di dalam dada bahwa puasa akan mensucikan diri pasien, sert memberi motivasi bahwa puasa adalah sarana detoksifikasi bagi pasien untuk mengeluarkan racun di dalam tubuh.

Sebagaimana puasa pada umumnya, pasien bangun sahur dan berbuka bersama.Namun ada pasien yang tidak tahan bahkan tidak mau berpuasa, sehingga terkadang hal ini menyulitkan terapis dan mengganggu konsentrasi pasien lain. Terhadap pasien ini, terapis dan perawat pengelola menempatkan pasien yang tidak berpuasa di tempat yang terpisah dengan pasien yang berpuasa.

Dengan berpuasa, pasien belajar untuk mengatur makanan yang masuk ke dalam perut pada waktu tertentu.Ia diajarkan untuk mengetahui hakikat dan nikmatnya berpuasa, sehingga diharapkan dapat memilih makanan yang sehat dan halal. Pasien juga belajar untuk bersikap jujur, baik pada diri sendiri maupun orang lain. Dengan melatih sikap ini, diharapkan terjadi perubahan perilaku pada diri pasien, agar pasien dapat diterima di keluarga dan masyarakat. ${ }^{50}$

\section{Analisis Data}

Peneliti mengelompokkan hasil observasi dan wawancara dalam beberapa tema. Hal-hal yang tampak secara lahiriah dan hal-hal terkait aspek perasaan yang diungkapkan pasien merupakan gambaran kondisi pasien penderita gangguan kejiwaan pada Pondok Inabah, sementara hal-hal yang diterapkan secara rutin dan berkelanjutan yang ditujukan untuk memperoleh keadaan fisik dan psikis yang normal merupakan gambaran teknik psikoterapi Islam yang digunakan.

Pasien penderita gangguan jiwa akibat penyalahgunaan narkoba pada Pondok Inabah memiliki ciri-ciri fisik yang relatif sama, yakni perawakan yang kurus, ditandai dengan berat badan yang berada di bawah garis nomal. Rambut yang dipotong pendek, sebagian besar

\footnotetext{
${ }^{50}$ Adi Riatmoko, Fitriadi, et all, Perawat dan Pengelola Pondok Inabah Banjarmasin, sebagai Informan, Wawancara dan Observasi, Banjarmasin Desember 2013.
} 
gundul, untuk memudahkan perawatan. Sebagian besar kurang memperhatikan penampilan, seperti kerapian dan kebersihan. Namun ketika menghadapi orang yang baru di lingkungannya mereka mampu bersikap sopan.

Mata pasien cenderung cekung dan kurang fokus ketika diajak berkomunikasi. Pasien sering menggerak-gerakkan anggota tubuh tertentu untuk memperoleh ketenangan saat proses wawancara, seperti meremas tangan, menyentuh daun telinga, menggosokkan kedua telapak tangan, mengetuk-ngetuk lantai dengan kuku.

Sebagian bibir pasien berwarna pucat atau kehitaman, sering terlihat menguap, mengantuk, dan gelisah saat observasi atau wawancara. Hal ini menunjukkan ciri-ciri fisik pengguna narkoba seperti dipaparkan Julianan Lisa: 1) Mata merah; 2) Mulut kering; 3) Bibir berwarna coklat berbercak kehitaman; 4) Bicara kacau; 5) Daya ingat menurun. ${ }^{51}$ Sumiati menyatakan bahwa pengguna narkoba mengalami perubahan fisik seperti penurunan berat badan, munculnya masalah kesehatan, serta penampilan yang buruk. ${ }^{52}$

Berdasarkan hasil observasi peneliti pada Pondok Inabah Banjarmasin, gangguan kejiwaan yang dialami pasien pada lokasi penelitian berupa gangguan mood, yaitu perubahan mood yang cepat pada pasien. Gangguan ini paling sering dilaporkan muncul di keluarga sebelum mereka berada di Pondok Inabah.

Pasien yang sensitif secara emosional merupakan pasien awal sedang mencoba beradaptasi, hal kecil seperti meminta rokok dapat menjadi perkelahian. Terdapat pasien yang mengalami retardasi mental, yaitu kemunduran kemampuan kognitif, seperti cara berfikir dan menarik kesimpulan yang tidak sesuai dengan usianya.

Menurunnya kemampuan kognitif lain seperti daya ingat, kemampuan konsentrasi, serta komunikasi yang terhambat. Sebagian tidak mampu mengontrol perilaku pada masa awal di Pondok Inabah.Pasien memiliki kepribadian yang sulit dipercaya, karena fikirannya hanya pada narkoba, hal ini ditandai dengan seringnya pasien berbohong baik di lingkungan keluarga atau saat berada di Pondok Inabah, sehingga perkataan pasien sulit dipercaya.

Pada pasien dengan gangguan psikis yang berat seperti depresi dan skizoprenia, mereka terlihat mau mengikuti kegiatan di Pondok, tapi terlihat seperti tanpa makna karena hilangnya kesadarannya.

Hasil penelitian ini sejalan dengan kondisi psikis pengguna narkoba dalam tulisan Sumiati, yakni "memiliki kemungkinan mengalami hilang ingatan, flash back, paranoid, serta perubahan mood.Pengguna merasa adanya perubahan emosi, seperti depresi, agresif, cepat tersinggung dan apatis". ${ }^{3}$

Gangguan psikis yang muncul dapat pula berupa menurunnya kemampuan kognitif yang ditandai dengan menurunnya daya ingat. ${ }^{54}$ Munculnya perasaan yang diinginkan seperti lebih aktif dan berani saat menggunakan narkoba sebagai cara untuk menutupi perasaan rendah diri yang ada pada diri mereka saat tidak menggunakan narkoba. ${ }^{55}$

\footnotetext{
${ }^{51}$ Julianan Lisa, Narkoba, Psikotropika, h.44-45, lihat juga Tina Afiatin, Pencegahan penyalahgunaan Narkoba, h. 29-30.

${ }^{52}$ Sumiati, Asuhan Keperawatan..., h. 31.

${ }^{53}$ Sumiati, Asuban Keperawatan..., h. 31

${ }^{54}$ Juliana Lisa, Narkoba Psikotropika..., h.45

${ }^{55}$ Juliana Lisa, Narkoba Psikotropika, h. 43-44. Lihat juga Sumiati, Asuban Keperawatan, h. 26-27
} 
Responden yang menggunakan narkoba tipe depresan, mengalami menurunnya pengendalian diri, hilangnya keterampilan fisik, gangguan konsentrasi, sebagaimana efek samping dalam tulisan Sumiati, yakni munculnya perilaku aneh atau menunjukkan tanda kebingungan proses berfikir, tidak bisa memberi pendapat dengan baik, gangguan konsentrasi dan keterampilan. ${ }^{56}$

Responden yang menggunakan narkoba tipe stimulan menunjukkan kondisi fisik yang ditandai dengan meningkatnya suhu badan, sering mengalami sakit kepala, berkeringat, mengalami halusinasi, kecemasan, sebagaimana tulisan Sumiati yang menyatakan bahwa pengguna narkoba tipe stimulan mengalami kehilangan nafsu makan yang menyebabkan meningkatnya suhu badan dan sering mengalami sakit kepala, serta muncul rasa letih, takut dan depresi. ${ }^{57}$ Pengguna narkoba jenis inhalan mengalami gangguan pengendalian diri, serta tidak mampu membuat keputusan, dapat mengalami halusinasi, serta kehilangan nafsu makan.

\section{Teknik Psikoterapi Islam yang digunakan}

\section{Mandi Tobat}

Mandi tobat layaknya mandi janabah dimaksudkan untuk mensucikan pasien dari hadast besar yang mungkin ia kerjakan pada keadaan tidak sadar, ataupun dikarenakan ia tidak mengetahui kewajiban mandi janabah tersebut. Diharapkan dapat menghantarkan pada awal kondisi suci pasien, sebagai momen beralihnya pasien dari kehidupan yang gelap menuju hidup yang bersih dan suci, serta penanda adanya keinginan untuk bertobat menuju kebaikan.

Beberapa pasien yang enggan atau tidak mau mengikuti proses ini, biasanya dibujuk dengan menggunakan istilah "mandi bungas". Dikatakan kepada pasien, jika ia menuruti prosesi pembersihan dengan mandi ini, ia akan terlihat lebih cantik, lebih ganteng, dan lebih bersih berseri. Sehingga mereka menjadi bersemangat dan mengikuti proses ini dengan suka rela.

Pada keadaan tertentu terdapat pasien yang mengamuk, sehingga tidak mau bekerja sama dengan terapis, maka terapis akan berusaha membujuk pasien agar mau bekerjasama dengan menjalani mandi janabah ini.

Rangkaian tobat yang dimulai dengan mandi tobat ini dilanjutkan dengan shalat tobat, mengucapkan istighfar serta memanjatkan doa permohonan ampun atas kesalahan dimasa lalu, dirasakan memberi perasaan tenang pada pasien, muncul harapan pada diri mereka bahwa mereka dapat kembali menjadi manusia yang baik. Hal ini menunjukkan tobat yang dilakukan membuka harapan bagi pasien akan kehidupan yang baru, tanpa bayangan masa lalu, serta menjadi aktifitas yang senantiasa diperbaharui agar semakin mengokohkan lembar yang masih putih. Serta berusaha untuk terus melatih jiwanya agar tidak tergiur kembali untuk berbuat maksiat. $^{58}$

\section{Zikir}

Zikir yang dijalankan pada Pondok inabah ini adalah zikir jahar dan zikir khafi. Zikir jahar atau zikir dengan lisan adalah menyebut lafazh zikirnya dengan huruf dan bersuara nyaring melalui lidah. Zikir Khafi atau zikir dengan hati berarti menyebut lafaz zikir dalam hati, tidak

\footnotetext{
${ }^{56}$ Sumiati, Asuban Keperawatan, h. 22

${ }^{57}$ Sumiati, Asuban Keperawatan, h. 19-20.

${ }^{58}$ Amir..., Ilmu Jiwa dalam tasawwuf h. 235-236
} 
bersuara dan berhuruf.Zikir dalam bentuk khafi ini dapat dilakukan dimana saja dan kapan saja bagi pasien yang besungguh-sungguh meniatkan dan melaksanakannya.

Lafaz yang diucapkan adalah: 1) 1). Zikir Nafi Itsbat, dengan mengucapkan "La ilaha Illa Allab" sebanyak seratus enam puluh lima kali setiap selesai shalat fardhu; 2) 2). Zikir Itsmu alZat, yaitu zikir yang langsung hanya menyebut kalimat Allah secara berulang-ulang kali. Zikir ini dinamakan juga zikir "Lathaif".

Dampak aktifitas zikir memang tidak terlihat secara langsung dalam penampilan fisik pasien, namun mereka mendapatkan perasaan nyaman setelah melepaskan energinya pada zikir jahar. Zikir yang dilakukan pasien secara kolektif dapat menguatkan niat dan taqwa pasien, serta menumbuhkan perasaan persaudaraan dan tolong menolong yang kuat dalam satu kehidupan sosial, sehingga akan melahirkan individu yang tidak mudah berputus asa serta tidak takut terhadap permasalahan kehidupan. ${ }^{59}$

\section{Shalat Khusyuk}

Pasien yang dapat diajak berkomunikasi dan berada pada gangguan kejiwaan ringan, dibimbing untuk melaksanakan shalat seratus rakaat yang dipandu terapi, dilakukan setiap hari saat pasien dirawat di Pondok Inabah. Shalat seratus rakaat disini merupakan istilah yang digunakan terapis untuk menggambarkan banyaknya bilangan shalat yang dikerjakan, walaupun rakaat yang dikerjakan tidak mutlak seratus rakaat.

Bimbingan mengenai urutan shalat, menghadirkan hati dalam shalat, serta dengan gerakan yang tuma'ninah diajarkan secara kontinu. Sebagian pasien yang merasakan nikmatnya shalat dapat mendapatkan perasaan tenang, dan menjadi senang untuk dekat dengan Allah yang diyakini akan mengampuni kesalahan mereka.

\section{Doa}

Doa yang dilakukan setelah shalat wajib menjadi harapan bagi pasien akan kesembuhan mereka. Sementara doa yang mereka panjatkan saat diminta ustaz untuk bertobat mengingat kesalahan mereka menjadi katarsis yang meringankan beban perasaan bersalah pasien, baik pada Allah yang mereka sempat lupakan serta pada keluarga yang sering mereka sakiti.

Perasaan-perasaan yang mereka tuangkan dalam bentuk doa dikatakan menjadi auto sugesti bagi mereka. Agar mereka dapat menjadi golongan yang mendapat petunjuk, rahmat, serta ampunan Allah. Yang menjadi momen bagi mereka untuk mengingat seperti apa mereka seharusnya berperilaku sebagai hamba.

Doa menjadi kekuatan bagi pasien dalam keadaan apapun, yang menghindarkan dari kegoncangan jiwa, sedih, takut, serta perasaan menderita. ${ }^{60}$ Karena doa dapat menjadi sarana bagi seseorang untuk mengungkapkan segala perasaannya di hadapan zat yang Mahatinggi dan Mahakuasa. ${ }^{61}$

\footnotetext{
${ }^{59}$ An Najar, Ilmu Jiwa dalam Tasammuf, h. 220.

${ }^{60}$ Musfir bin Said Az Zahrani, Konseling Terapi, h. 505-507.

${ }^{61}$ Ibrahim M. Hasan, Dahsyatnya doa untuk Kesembuhan, (Surakarta: Ziyad Visi Media, 2012.), h. 25.
} 


\section{Puasa}

Puasa sunah dijalankan pada senin-kamis, dan puasa wajib pada bulan Ramadhan.Pengelola menyiapkan sahur dan kegiatan berbuka dengan bantuan beberapa pasien yang mampu bekerjasama.Tidak semua pasien mampu menjalankan ibadah ini, ada yang puasa penuh, ada yang setengah hari, bahkan ada yang hanya ikut makan sahur dan berbuka, tapi tetap merokok di siang hari.

Sebagian pasien yang mampu menjalankan puasa mengaku memperoleh perasaan puas dan bangga saat berbuka, karena mampu menahan diri untuk makan, terutama merokok. Sehingga puasa menjadi sarana bagi pasien untuk belajar patuh dan takut pada Allah, senantiasa merasa diawasi, sehingga tidak mudah melakukan perbuatan buruk, kendati tidak ada seorangpun yang menyaksikan. Juga melatih kesabaran seseorang agar dapat memperoleh apa yang diinginkannya di waktu-waktu yang telah ditentukan.

Sebelum melaksanakan puasa pasien diberikan motivasi bahwa puasa merupakan teknik yang dapat mendetoksifikasi racun yang ada di dalam tubuh akibat penyalahgunaan narkoba. Pasien juga diarahkan untuk memiliki niat yang kuat di dalam hati bahwa dengan berpuasa ia akan menjadi lebih suci dan dapat mengendalikan jiwanya. Dengan motivasi dan niat yang kuat, pasien dapat memperoleh keadaan jiwa yang merasa bersih dan merasa lebih sehat dengan menjalankan teknik psikoterapi puasa ini.

\section{Penutup}

Kondisi umum pasien penderita gangguan kejiwaan akibat penyalahgunaan narkoba: 1) Kondisi fisik pasien pada umumnya memiliki berat badan yang berada di bawah batas normal, penampilan kurang menjaga kebersihan dan kerapian.Sering menggerak-gerakkan bagian tubuh untuk mendapatkan perasaan tenang. Terlihat mengantuk, bingung dan gelisah, mata cekung dan merah; 2) Kondisi psikis pasien yang terlihat adalah munculnya gangguan mood, gangguan beradaptasi, gangguan kontrol emosi, gangguan komunikasi, keadaan retardasi mental yang ditandai menurunnya kemampuan kognitif dan afektif.Pada pasien gangguan kejiwaan yang berat ditandai dengan depresi dan keadaan skizoprenia.

Teknik Psikoterapi Islam yang digunakan pada pasien gangguan kejiwaan akibat penyalahgunaan narkoba: 1) Mandi Tobat; 2) Zikir; 3) Shalat khusyuk; 4) Doa; dan 5) Puasa

\section{DAFTAR PUSTAKA}

Abdul Malik bin Muhammad Al-Qasim, (2005). Al-Fajr As-Shadiq, terj. Mubasabah menuju Penyucian Jiwa, oleh Ummu Mubarak, Solo: Pustaka Arafah.

Abdul Mujib, (2004). Apa Arti Tangisan Anda, Jakarta: Raja Grafindo Persada. , (2002). Nuansa-nuansa Psikologi Islam, Jakarta: Raja Grafindo Persada.

Adz Dzaky, Hamdani Bakran, (2007). Psikologi Kenabian, Prophetic Psychology, Yogyakarta : Beranda Publishing.

Al Fitrah, Muhammad, (t. th). Qalbu Yang Sakit, Jombang: Lintas Media.

Al Ikhwani, Fadlan, (2011). Dabsyatnya Bangun Pagi, Tahajjud, Subuh dan Dhuba, Surakarta: Ziyad Visi Media. 
Al Jauziyah, Ibnu Qayyim, (2004). Menuju Kesucian Hati, terjemahan Laghatsatul Labfan Min Mashaidiy Syaithon, oleh Nuroddin Usman, Lc. MA, Yogyakarta: Mardiyah Press.

Al Qardhawi, Yusuf, (2001). Berinteraksi dengan Al Qur'an, terjemahan Kaifa Nata amalu ma'a Al Qur'ani al azhim, oleh Abdul Hayyie al KAttani, Jakarta: Gema Insani Press.

Ali Shah, Omar, (2002). Tasawnf Sebagai Terapi, Bandung: Pustaka Hidayah.

Ali, Yunasril, Prof. (2009). Agar Shalat Jadi Penolongmu, Penyejuk Hatimu, Jakarta: Penerbit Zaman. Amir an-Najar, (2004). Psikoterapi Sufistik dalam Kebidupan Modern, Bandung: Penerbit Mizan. Amir an-Najar, (2004). Ilmu Jiwa Tasawnuf, Bandung: Penerbit Mizan.

Anas Ahmad Karzun, (2008). Syifa'un Nafs wa Ghidza'ur Rub terj. Nutrisi Hati Penyuci Ruhani oleh Arif Munandar, Wacana Ilmiah Press.

Baharuddin, (2002). Aktualisasi Psikologi Islam, YogyakartA: Fajar Pustaka Baru.

Bahnasi, Muhammad, ( 2007). Al-Shalat Hayat, terj. Shalat Sebagai Terapi Psikologi oleh Tiar Anwar Bahtiar, Bandung: Penerbit Mizan.

Basuki, Sulistyo, (2010). Metode Penelitian, Jakarta: Penaku.

Bin Said Az Jahrani, Musrin, (2005). Konseling Terapi, Jakarta: Gema Insani Pers.

Chaplin JP, (2008). Kamus Lengkap Psikologi, terjemahanThe Penguin Dictionary of Psychology DR. Kartini Kartono, Jakarta: PT. Raja Grafindo Persada.

D. Gray, Jerry, (2010). Rasulullah is My Doctorterj. Oleh Tetraswari, Jakarta: Penerbit Sinergi. Gunarsa, singgih, (2009). Konseling dan Psikologi, Jakarta: PT. BPK Gunung Mulia.

Ibnu Qayyim, (2004). Menuju Kesucian Hati, terjemahan Laghatsatul Labfan Min Mashaidiy Syaithon, oleh Nuroddin Usman, Lc. MA, Yogyakarta: Mardiyah Press.

Ibrahim M. Hasan, (2012). Al-Istisyfa' bid-du'a.terj. Dahsyatnya doa untuk Kesembuhan, Surakarta: Ziyad Visi Media.

Imam Jalaluddin Al Mahalli dan Iman Jalaluddin As Suyuti, 9t.th). Tafsir Jalalain Juz I, Bandung: $\mathrm{Al} \mathrm{Ma}$ arif.

Jaelani, Penyucian Jiwa (Tazkiyat al Nafs) dan Kesehatan Mental, Jakarta : PenerbitAzzami,

Jonathan A, Smith, (2001). Qualitative Psychology : Practical Guide to Research Methods, Yogyakarta: PP, 2009. Terjemahan Budi Santosa., S.Psi.

Julianan Lisa FR dan Nengah Sutrisna, (2013). Narkoba, Psikotropika dan Gangguan Jiwa, , Yogyakarta: Nuha Medika.

Kaelan, MS, (2010). Metode Penelitian Agama Kualitatif Interdisipliner, Yogyakarta: Paradigma.

Langgulung, Hasan, (1992). Teori - Teori Kesehatan Mental, Jakarta: Al Husna.

Malik B. Badri, (1996). The Dilemma of Muslim Psychologists, terj. Dilema Psikolog Muslim, Pustaka Firdaus.

M. Kamil Hasan, (2005). Al-Mausu'ah Al-Qur'aniyyah, Jakarta: terj. Prof. Alie Yafie.

McLeod, John, (2010). An Introduction to Counselling, terj. Pengantar Konseling oleh A.K. Anwar, Jakarta: Kencana Prenada Media.

Muhadjir, Noeng, (2000). Metode Penelitian edisi IV, Jakarta: Rake Sarasin.

Mujtahidin, (2012). Doa dan Terapi Khusus Bebas Insomnia Dan Gangguan Tidur, Jakarta: Pustaka Iman.

Mustamir, (2009). Potensi SQ, EQ, IQ Al Faatihah, Diva Press.

Najati, M. Ustman, (2008). The Ultimate Psychology, Oleh Hedi Fajar, Bandung: Pustaka Hidayah. 
Palmer, Stephen, (2011). Introduction to Counselling and Psychotherapy, terj. Konseling dan Psikoterapi, oleh Haris. H. Setiajid, Yogyakarta: Pustaka Pelajar.

Ramadhan, Majid, (2009). Arwa'ul Asrar, terj.Menangis Itu Sehat oleh Khalid Abdillah, , Surakarta: Ziyad Media.

Riyadi, Ahmad Ali, (2008). Psikologi Sufi Al Ghazali, Yogyakarta: Panji Pustaka.

Rizki Joko Sukmono, (2008). Psikologi Zikir, Jakarta: Raja Grafindo.

Sa'id bin Ali, (2003). Qiyamul Lail, terj. Tahajjud Nabi oleh Aris Munandar, Yogyakarta: Media Hidayah.

Shalih bin Shuwalih al-Hasawi, (2007). Al-Khasyyah wa al-buka', terj.Menangis Terapi Syar'i Melulubkan Kerasnya Hati oleh Widyan Wahyudi, Jakarta: Darul Haq.

Shaughressy, John, et al , (2012). Metode Penelitian dalam Psikologi, Research Methods in Psychology, terjemahan Ellys Tjo, M.Psi, Jakarta: Penerbit Salemba.

Sholeh, Muhammad, et.al, (2005). Agama Sebagai Terapi Telaah Menuju Ilmu Kedokteran Holistik, Yogyakarta: Pustaka Pelajar.

Siegfried Ebel, (1992). Synthetische Arzneimittel Ein lehr Und Handbugh, terj. Obat Sintetik sebuah buku pegangan.

Sumiati M,si, (2009). Asuban Keperawatan pada Klien Penyalahgunaan dan Ketergantungan NAPZA, , Jakarta: Trans Info Media.

Tan Hoan Tjay dan Kirana rahardja, (2002). Obat-Obat Penting, , Jakarta: Penerbit Gramedia.

Taufiq, M. Izzudin, (2006). Panduan Lengkap dan Praktis Psikologi Islam, diterjemahkan Oleh Sari Narulita. Lc. Jakarta: GemaInsani Pers.

Thohir Muhammad, Sp.Kj, (2009). Menjadi Manusia Pilihan dengan Jiwa Besar, Jakarta: Penerbit Lentera Hati.

Tina Afiatin, (2010). Pencegahan penyalahgunaan Narkoba dengan Program AJI, UGM, Press.

Tim Penyusun Fakultas Ushuluddin, (2004). Pedoman Penulisan Skripsi, Penerbit IAIN Antasari. 